CEPED-CICRED-INED Seminar on Female Deficit in Asia: Trends and Perspectives, Singapore, 5-7 December 2005. Draft paper before publication; please do not use it as reference

\title{
Gender Imbalances and the Twisted Marriage Market in Taiwan
}

\author{
Wen Shan Yang and Ying-ying Tiffany Liu
}

Institute of Sociology

and

Research Center for Social Sciences and Humanities

Academia Sinica, Taipei, Taiwan 


Abstract
Nowadays in Taiwan, for every four marriages there is one bride from overseas. It is
estimated that the rise of foreign brides will grow to even greater numbers in the coming years.
In this paper we use several indices to measure the imbalanced sex ratios since the 1970s. It is
found that the sex imbalance after the 1980s was at first favorable toward females in the
marriage market in Taiwan. But, after the opening of the Mainland China border to Taiwanese
tourists and business people in the mid-1980s, interethnic marriages between Taiwanese males
and Mainland Chinese females become possible. Brides from Mainland China have been
seeking a better life and improved economic opportunities in Taiwan. In addition, more foreign
brides from Vietnam, Indonesia, and Cambodia have also been coming to Taiwan to marry
Taiwanese males. A new marriage market has emerged after the influx of foreign brides to
Taiwan, and now it has shifted to becoming a marriage market that is unfavorable toward
Taiwanese females, especially those women of low education levels and living in rural areas.
We will discuss the causes and consequences of the sex imbalance in Taiwan in recent years,
with emphasis on the distorted marriage market now that foreign brides are a pivotal option




\section{Introduction}

In recent years the Taiwanese electronic mass media and newspapers have been full of news about "foreign brides" and "China brides." Apparently this reveals a recent trend in interethnic marriages which has gradually spread to today's Taiwanese society and has become a social phenomenon. Nowadays, those "foreign brides," their husbands, and children make up one of the important family forms in Taiwan. Undoubtedly, the growing proportion of foreign brides will bring the new activities and influences that may change Taiwanese society as a whole. The phenomenon of "foreign brides" can increase two important parts of the population balance equation, which is the changing fertility rate within a population and the immigrant population. All of these factors will definitely influence the developmental direction of the population in Taiwan in the future.

According to the Department of Statistics, Ministry of the Interior, until 2002 there were 93,100 foreigners married to Taiwanese citizens. On top of this number the Mainland Affairs Council has reported that 170,000 ethnically Mainland Chinese brides are registered on Taiwanese marriage licenses. If we calculate the marriage data from interethnic couples, there were 10,413 foreign spouses before the year of 1998. Among this number, 1,788 were grooms and 8,625 were brides, together accounting for $7.13 \%$ of the total registered marriages in Taiwan. In 2000, these numbers roughly doubled. Approximately 21,339 foreigners are now married to Taiwanese citizens, among them 2,277 grooms and 19,062 brides, or about $11.75 \%$ of total marriages in Taiwan. In 2002, interethnic marriages only grew by a small percentage as compared to the previous years. There were 20,107 interethnic couples registered for marriage licenses at the household registration office in Taiwan, and the vast majorities, 17,339 of them were foreign brides.

Basically, as the number of foreign brides is most likely to continue increasing in Taiwan in the future, the dynamics of the Taiwanese marriage market are sure to be altered, with little 
chance of a balance between the sexes in the marriage market in the long run. Since the foreign spouses made up approximately $12 \%$ of the total marriages and have been increasing more than 17,000 each year, this paper aims to discuss the ever changing marriage market in Taiwan as well as the dynamics of imbalanced sex ratios in the marriage market of Taiwan.

This study covers three areas of research. It starts with a brief introduction comparing the females' and males' opportunities to find a marriage partner during their 'marriageable age' by using the method of estimating the sex ratio of singles. Then, we will apply demographic techniques developed by two scholars, Schoen (1983) and Chen (2000), to analyze the marriage market in the Taiwanese context. Since the number of foreign brides is increasing rapidly in Taiwan, this paper will focus on this issue to conduct further analysis and explanation along with presenting the following research questions: what changes do foreign brides bring into Taiwan and how does it affect the Taiwanese marriage market? What are the reasons that bring 'foreign brides' to Taiwan? Moreover, what impact will they have on spousal availability for Taiwanese women?

\section{Marriage Match and Marriage Squeeze in Taiwan}

Family is one of the most important social institutions in a society. As we already know, family performs certain functions to maintain the stability of a social system: childbearing, socialization, education, economic production and emotional support-- these are basic to the existence of any given society. The key composition of a family is when a man and a woman reached marriageable age and are considering marriage. If an imbalanced sex ratio exists between males and females, it will lead to problems in the marriage market, such as the current problem of decreased spousal availability for Taiwanese women. Obviously, within a society which is strictly monogamous, if there is a surplus of men or vice versa; then, members of the minority sex group will have difficulties finding a spouse. For example, in post-World War II Germany, many women were unable to meet a potential marriage partner because of the 
insufficient numbers of males after the war. A more recent example is found in the Vietnamese People's Republic after 1975. Due to the large number of Vietnamese men killed in the war, Vietnamese women were at a disadvantage in the marriage market after the conflict (Goodkind, 1997). Furthermore, the mass migrations, both internationally and from rural to urban areas, may also create locally uneven sex ratios and further cause tightness in the marriage market. For instance, during the early $20^{\text {th }}$ century, a large number of young and middle-aged males immigrated to the U.S.A., which gave females who participated in the marriage market an advantage in spousal availability there (Akers, 1967).

Above are a few examples of how an absolute difference between the sexes can affect the availability during mating selection for both marriageable females and males. However, the tightness of marriage market is only partly explained by the absolute sex ratio difference. In fact, the main reasons why people who have reached marriageable age have difficulties in finding a potential spouse are relative gaps in age, socio-economic factors or social norms. Generally, men's spousal preference is to marry a woman who is two to four years younger. In this case, if the sex ratio of male births twenty-four years ago versus female births twenty to twenty-two years ago is greatly skewed, it will affect the chances to find a suitable marriage partner these many years later. The most famous case study is the baby boom generation born after the World War II era in the United States. As Akers (1967) pointed out, there were 1,900,000 female infants born between July 1946 to June 1947, while 1,500,000 male infants were born two years earlier (July 1944 - June 1945). During the 1970s, which was twenty years later, around 400,000 women were unable to find a marriage partner in the United States. As a result, they had to delay their marriage plan, marry someone much older or choose not to marry.

In the past several decades, the social scientists have thoroughly investigated these classic case studies in terms of the implications of imbalanced sex ratios for the marriage market in a specific society. From the previous findings we can see that besides the absolute difference in 
numbers between males and females as an influence on spousal availability, many other socio-demographic factors also cause imbalanced sex ratios, including marriage squeeze ${ }^{1}$, changes in birth rate over time, sex ratios at birth, and differential mortality at a local level as well as internationally. Since Taiwan has had a relatively closed border with other countries, the immigration and emigration have rarely affected the demographic dynamics in Taiwan. Therefore, it is the equilibrium state of mortality which has become the major factor affecting the demographic dynamics in terms of the changing age structure and long-term trend of fertility (Chen, Wang and Chen, 1986). Furthermore, the phenomenon of marriage squeeze will exist alongside these factors. The demographic transition has been completed in Taiwan, in other words, from a high fertility/mortality rate to low rates nowadays. The fertility rate in Taiwan has declined since the 1960s. The total fertility rate (TFR) in Taiwan has gradually declined from 7 children in 1951, to 5.6 children by 1961, and further to 2.5 and 1.8 children in 1981 and 1991. In 2000, it remained at 1.8 children per woman. Even if the sex ratios at birth are normal, this decline in fertility still can cause marriage squeeze for Taiwanese men; as mentioned above, men usually seek a woman who is two to four years younger as the ideal marriage partner, so a decline in fertility across a two- to four-year period results in a mismatch of numbers of available partners. On top of the low fertility rate and possible future reduction. The problems of imbalanced sex ratios will be even more problematic in the future and will situate the males in a serious disadvantaged situation in the marriage market.

\section{Demographic Measurements to Estimate Marriage Squeeze in Taiwan}

Akers (1967) was the first demographer to make an important attempt to measure the marriage squeeze for the U.S. due to an imbalance in sex ratios from the baby boom generation. Although later on Muhsam has also explored the measurement concept of "marriage squeeze",

\footnotetext{
1 When one sex group is relatively low owing to the shortage of potential spousal availably which are commonly known as a marriage squeeze in demographic studies (Goodkind, 1997).
} 
Akers's research work has had greater influence on the subsequent research pertinent to marriage squeeze studies. Akers has constructed mathematical models and simulations to explain a phenomenon which occurred in the late 1960s: there were many more females participating in the marriage market. According to Akers, the marriage squeeze index under his construction gradually turned to 91 in 1965, up from 104 in 1950, then increased to 105 in 1984, and kept decreasing each year. These results show there were, per 100 females at the age of 15-24, 104 males at the age of 15-29 in 1950, meaning that the males in this age group faced a problem in finding a marriage partner. Likely, there were similar problems of marriage squeeze for females in 1965. However the trend turned against men in the 1980s. During the years from 1959 to 1966 , Akers' simulation was close to successfully predicting the trends of marriage in 1970s' American society. He was especially correct about the increase in age of females at their first marriage, and males' and females' first marriage standardized age rates can be explained by this marriage squeeze index.

Chen (2000) has used a simple index to measure the marriage squeeze in Taiwan: the sex ratios of singles. According to the simple definition of this index, the marriage market can be defined as follows: under the marriage system of monogamy, the singles within the same age group who are seeking potential spouses in this "marriage market." However, this formula does not include the married people. The definition of this index is as follows:

Sex ratio of singles in i age group $=\frac{\text { population of single males in i age group }}{\text { population of single females in i age group }} \times 100$

Once this simple index is calculated, we can use its results to explain the influence from the sex ratios at birth on the singles in certain years from a historical experience of a population. Due to social custom, it is desirable that husbands be a few years older than the wives in Taiwan, so we also calculate the relevant sex ratios across spousal age gaps of one, two, and three years (that is, with men older by these spans of time). 
Schoen (1983) has revised and extended Akers' marriage squeeze index due to a lack of clear definition of its underlying concept. The index of marriage squeeze developed by Schoen contains a complex mathematical model. We incorporate this key concept in order to make further explanation. According to Schoen's (1983) index of marriage squeeze, marriage squeeze is related to the 'gender issue' in a formal demography. Briefly speaking, if the marriage preference remains constant, the changes in sex-age composition will affect the marriage rate, and will eventually result in marriage squeeze in a marriage market. For this reason, the interdependence of the observed age-sex composition and marriage rate can be used as the measurement index to reflect marriage squeeze in a population. The core index of marriage squeeze proposed by Schoen (1984) is represented by the S and Q equations as follows:

$$
\begin{aligned}
& S=\frac{\ell_{m ; c}(0)-\ell_{f ; c}(0)}{\ell_{m f ; c}(0)} \\
& Q=\frac{2 \ell_{m f ; c}(0)-\left[\ell_{m ; c}(0)+\ell_{f ; c}(0)\right]}{\ell_{m ; c}(0)+\ell_{f ; c}(0)}
\end{aligned}
$$

By definition, $\mathrm{S}$ and $\mathrm{Q}$ represent the marriage squeeze index and proportion of marriages lost because of marriage squeeze. When $\mathrm{S}$ is positive, the proportion of married males is greater than females; if $\mathrm{S}$ is negative, the proportion of married females is greater than males.

Two other measurements of marriage squeeze are also used in the study. They are both developed by Chen and Ulrich (2000) for the purposes of comparative marital supply in China and Germany. The first is called the marriage equilibrium index and the other is the first marriage squeeze index. The marriage equilibrium is represented by the equation 
Marriage Equilibrium Index $=\frac{e_{15}^{m}(m)-e_{15}^{f}(m)}{\max \left\{e_{15}^{m}(m), e_{15}^{f}(m)\right\}} \times 100$

Where $e_{15}^{m}(m)=\frac{\sum_{i \geq 15} L_{i}^{m} R_{i}^{m}}{l_{15}^{m}}, e_{15}^{f}(m)=\frac{\sum_{i \geq 15} L_{i}^{f} R_{i}^{f}}{l_{15}^{f}}$ are both life table functions, $e_{15}(m)$ represents the marriage life expectancy at 15 years of age; $m$ and $f$ are respectively male and female. By definition when marriage equilibrium index is negative, it reflects that life expectancy of married males is less than females in a population and an existing marriage squeeze toward males or vice versa. When the absolute value of marriage equilibrium is larger, the percentage of married life expectancy loss to marriage squeeze is greater, reflecting how serious the marriage squeeze is.

Chen and Ulrich (2000) developed another measurement of marriage squeeze, which they called the first marriage squeeze index. This index is more simple and straightforward:

First Marriage Squeeze Index $=\frac{M^{m}-M^{f}}{\max \left\{M^{m}, M^{f}\right\}} \times 100$

Where $M^{m}$ and $M^{f}$ are a total number of males and females at first marriages in a population at certain period. When the first marriage squeeze index is positive, the total males' first marriages are exceeding that of females, which reflects that the marriage market is unfavorable toward males; while when the first marriage squeeze is negative, it suggests that the total number of females' first marriages are greater than that of males in the population, representing a marriage market is unfavorable toward females. When the first marriage index is zero, the supply and demand of the marriage market have reached an equilibrium state, so marriage squeeze does not exist in the marriage market. When marriage squeeze is a serious issue in a population, the difference between males and females will be greater and the absolute value of first marriage will be higher. Chen and Ulrich develop a classification table to 
represent the types of marriage squeeze in a variety of supply and demand conditions in a population. We also adopted the table as a tool to explain the marriage squeeze situation of Taiwan in different time periods.

\section{Research Findings}

Tables 1-3 present the sex ratios of singles and the spousal age gaps in the years of 1980, 1990 and 2000 in Taiwan. Table 1 presents the sex ratios of singles over 15 years of age in 1980. This table reveals that, aside from changes at higher age levels (over 45), the sex ratios are almost constant from the ages of 15 to 50 . The sex ratios of singles at the same age can be seen as an absolute value of the proportion of single females and males. Although this cannot reflect the reality of the mating situation in the marriage market, in general it lets us know the numbers of marriageable singles from each sex group. As we can see from Table 1, in 1980, males were at a disadvantage, especially those between the ages 24 to 29 . This is nearly twice the single women from the same age group. Single men aged 30 to 40 were also more numerous than the single women from the same age group, and the sex ratios were about 185-124. Obviously within the same age group, the population of single males was larger than that of females. The sex ratios of singles in these age gaps show there was an increasing marriage squeeze problem for Taiwanese males because of the declining fertility after the baby boom generation in 1965 .

(Table 1-3 about here)

Furthermore, we inspect the ratios from these three groups: men one year older, two years older, and three years older-- these data can reflect the changes in birth rate and the sex ratios at birth in the past. This approach also takes the spousal age gaps into account. In brief, the age of 35 is the critical point regardless of whether men are two or three years older, and the sex ratios become more balanced gradually. However, the rate is much higher for the single men than for women over the age of 35 . Perhaps this reveals the important mechanism of marriage 
in Taiwan: single man 35-years-old or above with unstable employment status is more likely to stay away from the marriage because of frustration with seeking a marriage partner from the marriage market.

After 1990, the sex ratio of single males has gradually shifted to some extent in favor of males. In the total number of singles over 15 years of age, males' population is higher than females'; but the sex ratios are still within a normal range, about 105. Compared to the ages 26 - 33, single males are more numerous than females because men usually marry at a later age. Moreover, as we can see in the comparison between men one year, two years, and three years older, single males over age 40 are fewer than females. Although the proportion has declined gradually in all three groups after the age of 35 , the greatest reduction occurred in the one in which males are three years older. This is worthy of further research.

Table 3 exhibits the sex ratios of marriageable singles and the spousal age gaps in 2000 . Compared to Tables 1 and 2, there is not much difference amongst sex ratios of the total population over 15 years in the different age gaps. They are all less than 106 . However, we should pay attention to the growth in sex ratios in higher ages. As the example shows in Table 3 , the sex ratio is 131 at the age of 39 ; this reflects the fact that men usually marry at a later age. In these three groups, fewer single males over 38 and almost at 42 , the ratios tend to be balanced in both male and female groups.

The sex ratios of singles over age 15 in different calendar years are the results of the absolute total numbers of marriageable males and females in a population. This can be used to illustrate the proportion of single males and single females, and the total numbers of the singles in a population. The advantage is that it allows us to overview the mating situation in the current and future marriage market. On the other hand, it fails to observe the marriage rate in the marriage market, hence does not take marriage rates of a population into consideration in order to provide an empirical indicator when observing the mating situation in a population. Therefore, if we wish to study Taiwan's marriage market from a more comprehensive 
perspective, we should use another synthetic index which can reflect the supply and demand situations in the marriage market.

Table 4 presents the marriage squeeze indices and percentage of failure to marry caused by marriage squeeze in Taiwan area, Taipei City, and Kaohsiung City during 1975-2000.

According to Schoen, the marriage squeeze indices refer to the belief that men should marry younger women, leaving the older women wishing to get married fewer partnering options. The data in Table 4 are calculated from the observed marriage rate from each year. The data can reflect the sex and age structures and the marriage preference at that time. In 1985,1990 and 1995 the marriage squeeze indices of Taiwan area were negative, then shifted to positive in 2000. However, from 1975 to 2000 the marriage squeeze indices were all positive in Taipei City and Kaohsiung City. This result demonstrates that men were facing the marriage squeeze problems after 1980. That is, it was more difficult for men to find a potential spouse compared to women. Between 1975 and 1980, Taiwanese women were in a disadvantaged situation; this can be explained as the long-term effects from the baby boom generation. The growth of baby-boom generation population had made spousal availability lower for women before 1980 . However, age-sex composition of Taipei City and Kaohsiung City was not influenced by the baby boom after WWII or the excessive decline in birth rate after 1965 . In both districts the marriage squeeze affected women, making it difficult for them to find a single marriageable man (Chen and Liu, 2002). In fact, this reflected the presence of many international business headquarters as well as the governmental administrative agencies in both Taipei and Kaohsiung cities, which attracted young women to move to these cities for educational purpose and for career opportunities, because service jobs are highly needed. As a result, the age-sex composition has been changed, further reducing spousal availability.

(Table 4 about here)

It is noteworthy that in 2000 the marriage squeeze indices were negative then shifted to positive. This deserves further consideration as to whether this result was produced by 
immigration of foreign brides to Taiwan. Since Schoen's marriage squeeze indices are calculated by using the observed marriage rates from the marriage life expectation index for each sex, the guiding assumption is that the rise in males' marriage rates might be mainly caused by interethnic marriages -- that is, a mass of marriageable Taiwanese males marrying Chinese or other foreign brides. Q means loss of marriages caused by marriage squeeze, and it is less than 1, reflecting the fact that an increase in marriage rates for one particular sex group occurred because there is a marriage squeeze problem hitting the other sex group.

Table 5 presents marriage life expectation indices from 1966 to 2000 in Taipei City, Kaohsiung City, and the remainder of Taiwan area by utilizing the methods developed by Chen and Ulrich (2000). This data demonstrates that the sex ratios are out of balance. In other words, a great absolute value of marriage life expectation index means a surplus of women or men, as well as a high percentage singles failure to marry caused by marriage squeeze. Most importantly, how serious the problems of marriage squeeze is. In Table 6 we divided the marriage markets into three standard types of marriage market. Moreover, three types of marriage market conditions are possible: surplus of males, males/females balanced and surplus of females. These conditions were calculated using the technique developed by Chen and Ulrich (2000) marriage life expectation indices.

Table 5 indicates that the marriage squeeze problem had peak in 1966. By 1995 the index had fallen to nearly -4 . The marriage life expectation index shows that men were in excess supply, but eased up in 1975; the excess then reoccurred between 1980 and 1990. Due to the limited information, we only calculate the marriage life expectation from Taipei City, Kaohsiung City, and the remainder of Taiwan in 1990 and 2000. The results show that there was a surplus of men in the rest of Taiwan, as well as in Kaohsiung City in 1990. Sex ratios were almost balanced in Kaohsiung in 2000 as well as in Taipei in 1990; however, a high surplus of women in Taipei in 2000.

(Table 5 and 6 about here) 
Table 7 shows the calculation from the marriage squeeze indices at first marriage between the years of 1980 to 2000 in the following areas: Taiwan area, Taipei city and Kaohsiung city. If the marriage squeeze index at first marriage is positive, it means that during a certain period there were more males participating in the marriage market. By contrast, if the indices are negative, more females than males joined the marriage market. When the indices are 0 , males and females are equal in number; it can be said the supply and demand in a given marriage market are temporarily balanced. Before 1995, men and women were nearly balanced temporarily. However, starting from 2000 it appears there was a high surplus of women. This can be seen as a result of Taiwanese men becoming more likely to marry foreigners. This phenomenon has greatly influenced the marriage squeeze index at first marriage. Starting from the year 2000, the problem of a relative excess in the female population has occurred. The index of marriage squeeze at first marriage was at that point -6.8 and -7.17 in Taipei City and Kaohsiung City respectively; both cities had a problem of surplus women. This result is similar to the marriage life expectation index and is the characteristic of urbanized cities.

(Table 7 about here)

\section{Discussion and Conclusion}

Chen (1988) in her comparative study of Taiwanese and American marriage markets demonstrates that Becker's concept of marriage market is not viable to prove that Taiwan was facing a marriage squeeze problem. In this paper we have used three different marriage squeeze indexes in order to calculate whether the Taiwanese marriage market has such a problem. Our research findings are similar, regardless of whether the formulas used were from Schoen, Chen or Ulrich. Women were at a disadvantage in the marriage market before 1980 . After 1980, due to the fertility rate shrinking each year, the marriage market became unfavorable to males, especially in Taiwan and several other countries where its fertility has 
declined since mid 1960. As the results suggest, there was a shortage of women, hence many of the men of a marriageable age were unlikely to find a potential spouse.

Notwithstanding, there was a great "unexpected" transition in Taiwan's marriage market after late 1990s. According to our calculations from 1980 to 2000 in each county and city, the marriage squeeze indices at first marriage suggest that women are disadvantaged in the eastern area and middle/southern agricultural areas in 2000. The female population has exceeded the amount required in all counties and cities in Taiwan except rural areas such as Taidong County and Penghu County; meanwhile, a mass of "foreign brides" from Southeast Asian countries and Mainland China immigrated to Taiwan beginning in the 1990s and this trend still continues in present time. Evidently, there are 17,000 more interethnic marriages occurring in Taiwan each year, an increase of nearly $12 \%$ of the total marriages each year since 1997 . Apparently this recent trend in interethnic marriages has spread to every corner of today's Taiwanese society and has become a common practice among Taiwanese males.

As one important question asked previously: what changes do foreign brides bring into Taiwan and how does it affect the Taiwanese marriage market? We argue that this is the most likely factor that caused such a transition in the marriage market, which now Taiwanese women in a relatively difficult situation in relation to the marriage squeeze. In other words, the marriage squeeze turned against Taiwanese females due to a mass of foreign brides immigrated to Taiwan with marriage permits.

In addition, the foreign brides' country of origin data and the data on interethnic marriages from each province of Mainland China are not available yet, making it impossible to calculate the marriage squeeze indices at first marriage more precisely between foreign brides and Taiwanese males. Since Taiwan and Mainland China share similar culture and history; many of the Taiwanese men prefer the 'China brides.' However, because it is harder for the China brides to obtain Taiwanese residence permits, hence the data do not cover those brides who 
commute between China and Taiwan and did not settle in Taiwan at current time. Therefore, Taiwanese women's real spousal availability maybe overestimated after 2000.

In recent years, the discussion on marriage issues, especially the research about the foreign brides, mainly focuses on foreign brides' adaptation (Hsia, 2002), transnational or interethnic marriages, and the domestic labor market (Wang, 2002). These studies have concentrated on the issue of marriage market and discussion on "the supply" of foreign brides. However, they neglect problems of "the demand" in Taiwan's marriage market. Due to the immigration of foreign brides to Taiwan, the number of men who face the marriage squeeze problem has greatly declined, and for them, the problem appears 'solved.' But this has placed women in a similar predicament which appears to be worsening, especially for women with lower education, living in rural areas, or belonging to the lower classes, with less opportunity for upward mobility. We argue that this problem will get worse if the foreign brides keep entering Taiwan. In the near future, Taiwanese males will have better spousal availability in the marriage market as the situation unexpectedly changes to a surplus of marriageable women. This will affect females' possibility of finding a marriage partner in the Taiwan marriage market.

Undoubtedly, this topic deserves the attention of demographers and the administrative experts on population policy. The Taiwanese marriage market has begun changing, and the rate of transformation may increase as the trend of interethnic marriages becomes stronger. In a modern society, social and parental pressures are unable to drive people to marry against their will. Rather, marriage is a free choice. Therefore, how to develop a better methodology that can encourage people to successfully find mates is an important challenge for Taiwan's future marriage market. 


\section{References}

Akers, D. S. (1967). On Measuring the Marriage Squeeze. Demography, 4, 907-924.

Chen Chao-Nan and Ke-Chih Liu. (2002). An Evaluation of Taiwan's Year 2000

Census: A Comparative Study of Census and Household Registration Population. Journal Taiwan Population, 25, 1-56.

Chen, Wen-Ling. (1988). A Comparative Study of Taiwan and US Marriage Market. Taiwan Bank Quarterly. 39, 397-409. (In Chinese)

Chen, You-Hua and Mueller Ulrich. (2000). Comparative Study on Marital Supply and Demand in China and Germany. Population \& Economics, 5, 3-17. (In Chinese)

Goodkind, Daniel. (1997). The Vietnamese Double Marriage Squeeze. International Migration Review, 31 (1), 108-127.

Hsia, Hiaso Jun. (2002). Beyond the Imaginable Coast: The Phenomenon of Foreign Brides and International Capitalism. Journal of Taiwan Social Research Book Series-09. (In Chinese)

Muhsam, H. V. (1974). The Marriage Squeeze. Demography, 11, 291-299.

Schoen, R. (1983). Measuring the Tightness of a Marriage Squeeze. Demography, 20, 61-78.

Schoen, R. (1988). Modeling Multigroup Populations. New York: Plenum Press.

Wang, Hong-Zen. (2001). A Social Stratification Study of International Marriage and Indigenous Labor Market: A Case Study of Viet Nam Brides. Journal of Taiwan Social Research, 41, 99-127. (In Chinese) 


\section{Appendix:}

Table 1: Sex Ratios of Marriageable Singles, and Sex Ratio of Single Males by Age Gaps in 1980.

\begin{tabular}{|c|c|c|c|c|c|c|c|}
\hline \multirow[b]{2}{*}{ Age } & \multicolumn{2}{|c|}{$\begin{array}{c}\text { Percentage of } \\
\text { Singles }\end{array}$} & \multirow[b]{2}{*}{$\begin{array}{c}\text { Sex Ratio } \\
\text { by Ages }\end{array}$} & \multicolumn{4}{|c|}{ Sex Ratio of Singles } \\
\hline & Males & Females & & $\begin{array}{l}\text { Same } \\
\text { Age }\end{array}$ & $\begin{array}{c}\text { Men One } \\
\text { Year } \\
\text { Older }\end{array}$ & $\begin{array}{c}\text { Men Two } \\
\text { Years } \\
\text { Older }\end{array}$ & $\begin{array}{l}\text { Men } \\
\text { Three } \\
\text { Years } \\
\text { Older }\end{array}$ \\
\hline 15 & 99.92 & 99.51 & 104.97 & 105.41 & - & - & - \\
\hline 16 & 99.84 & 98.41 & 105.79 & 107.34 & 108.05 & - & - \\
\hline 17 & 99.63 & 96.26 & 105.01 & 108.68 & 108.38 & 109.10 & - \\
\hline 18 & 98.94 & 92.65 & 105.51 & 112.68 & 108.11 & 107.81 & 108.52 \\
\hline 19 & 97.41 & 87.05 & 104.93 & 117.41 & 109.87 & 105.41 & 105.12 \\
\hline 20 & 95.52 & 79.78 & 103.45 & 123.86 & 112.60 & 105.37 & 101.09 \\
\hline 21 & 94.50 & 69.80 & 102.18 & 138.35 & 121.33 & 110.30 & 103.22 \\
\hline 22 & 91.24 & 59.06 & 103.27 & 159.54 & 130.85 & 114.76 & 104.33 \\
\hline 23 & 83.15 & 47.89 & 103.86 & 180.34 & 138.75 & 113.80 & 99.80 \\
\hline 24 & 72.71 & 37.31 & 104.58 & 203.83 & 164.85 & 126.83 & 104.02 \\
\hline 25 & 59.75 & 28.53 & 105.62 & 221.17 & 164.54 & 133.07 & 102.38 \\
\hline 26 & 47.54 & 22.15 & 105.11 & 225.65 & 165.54 & 123.16 & 99.60 \\
\hline 27 & 37.81 & 17.48 & 105.23 & 227.65 & 172.41 & 126.49 & 94.10 \\
\hline 28 & 30.31 & 14.41 & 105.82 & 222.55 & 180.75 & 136.90 & 100.44 \\
\hline 29 & 23.13 & 12.06 & 105.19 & 201.71 & 169.26 & 137.47 & 104.12 \\
\hline 30 & 18.45 & 10.59 & 106.74 & 185.89 & 137.52 & 115.40 & 93.73 \\
\hline 31 & 15.39 & 9.28 & 106.54 & 176.67 & 145.09 & 107.34 & 90.07 \\
\hline 32 & 12.63 & 8.35 & 106.93 & 161.79 & 127.41 & 104.64 & 77.41 \\
\hline 33 & 11.27 & 7.92 & 106.24 & 151.21 & 127.15 & 100.13 & 82.23 \\
\hline 34 & 10.58 & 7.00 & 106.55 & 161.07 & 117.14 & 98.50 & 77.57 \\
\hline 35 & 10.03 & 6.53 & 106.19 & 163.08 & 137.66 & 100.11 & 84.18 \\
\hline 36 & 9.03 & 6.22 & 106.32 & 154.42 & 172.83 & 145.90 & 106.10 \\
\hline 37 & 8.47 & 6.03 & 106.27 & 149.30 & 147.62 & 165.22 & 139.47 \\
\hline 38 & 8.16 & 6.02 & 105.46 & 142.89 & 142.66 & 141.06 & 157.87 \\
\hline 39 & 7.97 & 6.18 & 105.76 & 136.35 & 140.95 & 140.72 & 139.14 \\
\hline 40 & 7.93 & 6.43 & 104.27 & 128.63 & 136.25 & 140.84 & 140.61 \\
\hline 41 & 7.84 & 6.47 & 102.95 & 124.81 & 121.12 & 128.29 & 132.61 \\
\hline 42 & 8.00 & 6.88 & 103.66 & 120.4 & 121.23 & 117.64 & 124.60 \\
\hline 43 & 8.31 & 7.31 & 103.85 & 117.95 & 124.49 & 125.35 & 121.64 \\
\hline 44 & 8.46 & 7.67 & 104.45 & 115.14 & 115.14 & 121.53 & 122.37 \\
\hline 45 & 8.70 & 8.19 & 104.55 & 111.12 & 119.03 & 119.03 & 125.64 \\
\hline 46 & 9.20 & 8.50 & 108.65 & 117.59 & 117.06 & 125.39 & 125.39 \\
\hline 47 & 10.42 & 9.16 & 114.72 & 130.52 & 134.57 & 133.96 & 143.50 \\
\hline 48 & 11.63 & 9.66 & 121.63 & 146.41 & 150.62 & 155.30 & 154.59 \\
\hline 49 & 13.86 & 10.73 & 130.42 & 168.48 & 185.76 & 191.10 & 197.03 \\
\hline $50+$ & 23.47 & 25.76 & 111.84 & 101.93 & - & - & - \\
\hline
\end{tabular}

Sources: 1980 census in Taiwan area, by households 
Table 2: Sex Ratios of Marriageable Singles, and Sex Ratio of Single Males by Age Gaps in 1990.

\begin{tabular}{|c|c|c|c|c|c|c|c|}
\hline \multirow[b]{2}{*}{ Ages } & \multicolumn{2}{|c|}{$\begin{array}{l}\text { Percentage of } \\
\text { Singles }\end{array}$} & \multirow[b]{2}{*}{$\begin{array}{c}\text { Sex Ratio } \\
\text { by Ages }\end{array}$} & \multicolumn{4}{|c|}{ Sex Ratio of Singles } \\
\hline & Males & Females & & $\begin{array}{l}\text { Same } \\
\text { Age }\end{array}$ & $\begin{array}{c}\text { Men One } \\
\text { Year } \\
\text { Older }\end{array}$ & $\begin{array}{c}\text { Men Two } \\
\text { Years } \\
\text { Older }\end{array}$ & $\begin{array}{l}\text { Men } \\
\text { Three } \\
\text { Years } \\
\text { Older }\end{array}$ \\
\hline 15 & 99.70 & 99.48 & 105.48 & 105.71 & - & - & - \\
\hline 16 & 99.61 & 98.98 & 105.37 & 106.04 & 103.99 & - & - \\
\hline 17 & 99.43 & 97.97 & 106.13 & 107.71 & 105.84 & 103.79 & - \\
\hline 18 & 99.02 & 96.55 & 105.09 & 107.77 & 108.79 & 106.90 & 104.83 \\
\hline 19 & 98.31 & 94.12 & 106.12 & 110.85 & 111.35 & 112.41 & 110.45 \\
\hline 20 & 97.39 & 90.07 & 109.45 & 118.35 & 116.33 & 116.86 & 117.97 \\
\hline 21 & 96.50 & 84.94 & 108.75 & 123.56 & 117.82 & 115.81 & 116.33 \\
\hline 22 & 94.82 & 77.42 & 109.27 & 133.82 & 121.21 & 115.58 & 113.60 \\
\hline 23 & 90.81 & 68.39 & 108.32 & 143.83 & 120.27 & 108.93 & 103.87 \\
\hline 24 & 85.93 & 59.24 & 105.88 & 153.58 & 145.77 & 121.89 & 110.40 \\
\hline 25 & 77.89 & 49.04 & 105.40 & 167.40 & 136.22 & 129.30 & 108.11 \\
\hline 26 & 69.25 & 39.75 & 105.80 & 184.35 & 150.77 & 122.69 & 116.45 \\
\hline 27 & 58.43 & 31.19 & 104.60 & 195.98 & 155.35 & 127.06 & 103.39 \\
\hline 28 & 50.03 & 25.22 & 105.06 & 208.39 & 167.12 & 132.48 & 108.35 \\
\hline 29 & 41.40 & 21.12 & 104.97 & 205.77 & 170.45 & 136.69 & 108.36 \\
\hline 30 & 34.07 & 17.86 & 105.57 & 201.41 & 167.84 & 139.02 & 111.49 \\
\hline 31 & 28.31 & 15.90 & 104.59 & 186.18 & 166.01 & 138.34 & 114.59 \\
\hline 32 & 24.62 & 14.56 & 104.82 & 177.23 & 155.42 & 138.58 & 115.48 \\
\hline 33 & 20.87 & 13.51 & 104.18 & 160.93 & 142.54 & 125.00 & 111.46 \\
\hline 34 & 18.28 & 12.57 & 104.77 & 152.36 & 148.28 & 131.34 & 115.18 \\
\hline 35 & 16.11 & 12.14 & 105.11 & 139.46 & 131.64 & 128.11 & 113.47 \\
\hline 36 & 14.79 & 11.79 & 104.98 & 131.71 & 120.68 & 113.91 & 110.86 \\
\hline 37 & 13.12 & 11.69 & 104.31 & 117.10 & 111.41 & 102.09 & 96.36 \\
\hline 38 & 12.25 & 11.56 & 105.12 & 111.45 & 109.17 & 103.87 & 95.17 \\
\hline 39 & 11.43 & 11.32 & 104.51 & 105.51 & 104.21 & 102.08 & 97.12 \\
\hline 40 & 10.85 & 11.26 & 105.82 & 101.98 & 85.07 & 84.02 & 82.30 \\
\hline 41 & 10.32 & 11.18 & 105.45 & 97.32 & 91.68 & 76.48 & 75.54 \\
\hline 42 & 9.79 & 12.26 & 103.77 & 82.84 & 80.23 & 75.58 & 63.04 \\
\hline 43 & 9.52 & 10.66 & 105.16 & 93.91 & 70.85 & 68.62 & 64.64 \\
\hline 44 & 9.59 & 10.51 & 104.80 & 95.62 & 79.07 & 59.65 & 57.77 \\
\hline 45 & 9.48 & 10.49 & 103.59 & 93.62 & 84.80 & 70.13 & 52.90 \\
\hline 46 & 8.82 & 10.57 & 103.58 & 86.40 & 101.85 & 92.26 & 76.29 \\
\hline 47 & 8.62 & 10.53 & 103.77 & 85.01 & 85.26 & 100.50 & 91.04 \\
\hline 48 & 8.50 & 10.74 & 102.52 & 81.13 & 83.06 & 83.29 & 98.19 \\
\hline 49 & 8.52 & 11.51 & 102.86 & 76.13 & 83.04 & 85.01 & 85.26 \\
\hline $50+$ & 20.52 & 30.75 & 115.77 & 77.23 & - & - & - \\
\hline
\end{tabular}

Sources: 1990 census in Taiwan area, by households 
Table 3: Sex Ratios of Marriageable Singles, and Sex Ratio of Single Males by Age Gaps in 2000.

\begin{tabular}{|c|c|c|c|c|c|c|c|}
\hline \multirow[b]{2}{*}{ Ages } & \multicolumn{2}{|c|}{$\begin{array}{c}\text { Percentage of } \\
\text { Singles }\end{array}$} & \multirow[b]{2}{*}{$\begin{array}{c}\text { Sex Ratio } \\
\text { by Ages }\end{array}$} & \multicolumn{4}{|c|}{ Sex Ratio of Singles } \\
\hline & Males & Females & & $\begin{array}{l}\text { Same } \\
\text { Age }\end{array}$ & $\begin{array}{c}\text { Men One } \\
\text { Year } \\
\text { Older }\end{array}$ & $\begin{array}{c}\text { Men Two } \\
\text { Years } \\
\text { Older }\end{array}$ & $\begin{array}{l}\text { Men } \\
\text { Three } \\
\text { Years } \\
\text { Older }\end{array}$ \\
\hline 15 & 99.66 & 99.57 & 106.33 & 106.43 & - & - & - \\
\hline 16 & 99.61 & 99.30 & 106.54 & 106.88 & 114.14 & - & - \\
\hline 17 & 99.49 & 98.64 & 105.97 & 106.88 & 109.73 & 117.19 & - \\
\hline 18 & 99.28 & 97.18 & 105.32 & 107.60 & 111.98 & 114.97 & 122.79 \\
\hline 19 & 98.81 & 95.03 & 104.77 & 108.95 & 109.99 & 114.46 & 117.52 \\
\hline 20 & 97.90 & 91.69 & 105.08 & 112.19 & 108.15 & 109.18 & 113.63 \\
\hline 21 & 97.06 & 88.64 & 106.38 & 116.48 & 116.11 & 111.93 & 113.00 \\
\hline 22 & 95.61 & 84.56 & 105.93 & 119.78 & 112.49 & 112.13 & 108.09 \\
\hline 23 & 92.90 & 78.74 & 104.96 & 123.83 & 111.02 & 104.27 & 103.93 \\
\hline 24 & 90.35 & 73.78 & 105.27 & 128.91 & 130.91 & 117.37 & 110.23 \\
\hline 25 & 85.03 & 65.72 & 104.12 & 134.73 & 105.34 & 106.98 & 95.91 \\
\hline 26 & 79.35 & 58.10 & 102.55 & 140.05 & 123.56 & 96.61 & 98.11 \\
\hline 27 & 71.24 & 49.03 & 103.51 & 150.39 & 125.85 & 111.03 & 86.82 \\
\hline 28 & 65.81 & 43.14 & 103.44 & 157.80 & 138.12 & 115.58 & 101.97 \\
\hline 29 & 58.03 & 36.91 & 104.44 & 164.21 & 143.70 & 125.77 & 105.25 \\
\hline 30 & 50.92 & 31.82 & 105.03 & 168.11 & 148.16 & 129.66 & 113.49 \\
\hline 31 & 44.31 & 27.86 & 105.08 & 167.15 & 146.42 & 129.05 & 112.93 \\
\hline 32 & 39.67 & 24.66 & 106.15 & 170.74 & 150.44 & 131.78 & 116.14 \\
\hline 33 & 35.34 & 22.41 & 106.21 & 167.50 & 144.48 & 127.30 & 111.51 \\
\hline 34 & 31.53 & 20.67 & 105.47 & 160.89 & 159.22 & 137.34 & 121.01 \\
\hline 35 & 28.88 & 19.33 & 105.08 & 156.99 & 145.46 & 143.94 & 124.16 \\
\hline 36 & 26.26 & 18.31 & 105.42 & 151.15 & 144.83 & 134.19 & 132.79 \\
\hline 37 & 23.85 & 17.39 & 104.79 & 143.74 & 138.93 & 133.13 & 123.35 \\
\hline 38 & 22.13 & 16.72 & 104.56 & 138.42 & 130.78 & 126.40 & 121.12 \\
\hline 39 & 20.40 & 16.25 & 104.20 & 130.87 & 125.37 & 118.45 & 114.48 \\
\hline 40 & 18.85 & 16.04 & 104.34 & 122.64 & 119.68 & 114.65 & 108.32 \\
\hline 41 & 17.90 & 15.76 & 103.26 & 117.26 & 114.74 & 111.97 & 107.27 \\
\hline 42 & 16.96 & 15.65 & 103.06 & 111.70 & 107.56 & 105.24 & 102.71 \\
\hline 43 & 15.79 & 15.54 & 102.39 & 104.01 & 98.08 & 94.45 & 92.42 \\
\hline 44 & 14.94 & 15.48 & 102.62 & 99.03 & 101.84 & 96.03 & 92.48 \\
\hline 45 & 14.17 & 15.64 & 102.74 & 93.07 & 91.82 & 94.42 & 89.04 \\
\hline 46 & 13.69 & 15.80 & 101.53 & 87.98 & 84.50 & 83.37 & 85.73 \\
\hline 47 & 13.00 & 16.11 & 101.58 & 81.98 & 80.65 & 77.47 & 76.43 \\
\hline 48 & 12.57 & 16.30 & 101.80 & 78.48 & 77.47 & 76.22 & 73.21 \\
\hline 49 & 11.76 & 16.51 & 100.63 & 71.65 & 74.09 & 73.14 & 71.96 \\
\hline $50+$ & 10.86 & 19.93 & 97.92 & 53.34 & - & - & - \\
\hline
\end{tabular}

Sources: 2000 census in Taiwan area, by households 
Table 4: Marriage Squeeze Indices and Percentage of Failure to Marry Caused by Marriage Squeeze in Taiwan area, Taipei City, and Kaohsiung City.

\begin{tabular}{c|cc|cc|cc}
\hline \hline \multirow{2}{*}{ Year } & \multicolumn{2}{|c|}{ Taiwan Area } & \multicolumn{2}{|c|}{ Taipei City } & \multicolumn{2}{c}{ Kaohsiung City } \\
\cline { 2 - 7 } & $\mathrm{S}$ & $\mathrm{Q}$ & $\mathrm{S}$ & $\mathrm{Q}$ & $\mathrm{S}$ & $\mathrm{Q}$ \\
\hline 1975 & 0.01283 & 0.000563 & 0.019534 & 0.00067 & 0.029198 & 0.002738 \\
1980 & 0.002068 & 0.000002 & 0.040503 & 0.0042 & 0.02359 & 0.002018 \\
1985 & -0.00898 & 0.000156 & 0.045628 & 0.002979 & 0.02472 & 0.000844 \\
1990 & -0.03762 & 0.001207 & 0.04884 & 0.001948 & 0.016247 & 0.00022 \\
1995 & -0.00446 & 0.000003 & 0.068237 & 0.004863 & 0.0326 & 0.001043 \\
2000 & 0.041483 & 0.002186 & 0.090175 & 0.008692 & 0.081002 & 0.006701 \\
\hline \hline
\end{tabular}

Note: Kaohsiung City was not a Municipal City in 1975; all calculations in Taiwan Province, Taipei City, and Kaohsiung City are in accordance with Census over past few years. 
Table 5: Marriage Life Expectation Indices in Taiwan, the remainder of Taiwan area, Taipei City, and Kaohsiung City.

\begin{tabular}{|c|c|c|c|c|}
\hline Year & Taiwan Area & Taiwan & Taipei City & Kaohsiung City \\
\hline 1966 & -25.997 & & & \\
\hline 1970 & -10.1055 & & & \\
\hline 1975 & -4.40627 & & & \\
\hline 1980 & -7.42171 & & & \\
\hline 1985 & -8.73739 & & & \\
\hline 1990 & -6.08004 & -7.61056 & 1.435177 & -3.59302 \\
\hline 1995 & -4.58346 & & & \\
\hline 2000 & -4.22226 & -6.24756 & 4.522801 & -0.31746 \\
\hline
\end{tabular}


Table 6: Standard Types of Marriage Market, by Chen and Ulrich

\begin{tabular}{cccc}
\hline Types of & Marriage Life & Marriage Squeeze Indices & Remarks \\
Marriage Market & Expectation Index & at First Marriage & \\
\hline \multirow{2}{*}{ Surplus Males } & Between: $<-4$ & Between: $>4$ & High Surplus \\
& $-3 \sim-4$ & $3 \sim 4$ & Medium Surplus \\
& $-2 \sim-3$ & $2 \sim 3$ & Light Surplus \\
\hline Males/females balanced & $-2 \sim 2$ & $-2 \sim 2$ & Light Surplus \\
\hline Surplus Females & $>2$ & $<-2$ & Medium Surplus \\
& $3 \sim 4$ & Between:-2 -3 & High Surplus \\
\hline \hline
\end{tabular}


Table 7: Marriage Squeeze Indices at First Marriage in Taiwan Area, Taiwan, Taipei City, and Kaohsiung City.

\begin{tabular}{c|cccc}
\hline \hline Year & Taiwan Area & Taiwan & Taipei City & Kaohsiung City \\
\hline 1980 & 0.251334 & 0.50124 & -1.13837 & -0.27174 \\
1990 & 0.367955 & 0.536489 & -0.75309 & 0.543411 \\
1995 & -0.83884 & -0.49216 & -2.85083 & -1.36585 \\
2000 & -5.44588 & -5.12232 & -6.8204 & -7.16661 \\
\hline \hline
\end{tabular}

